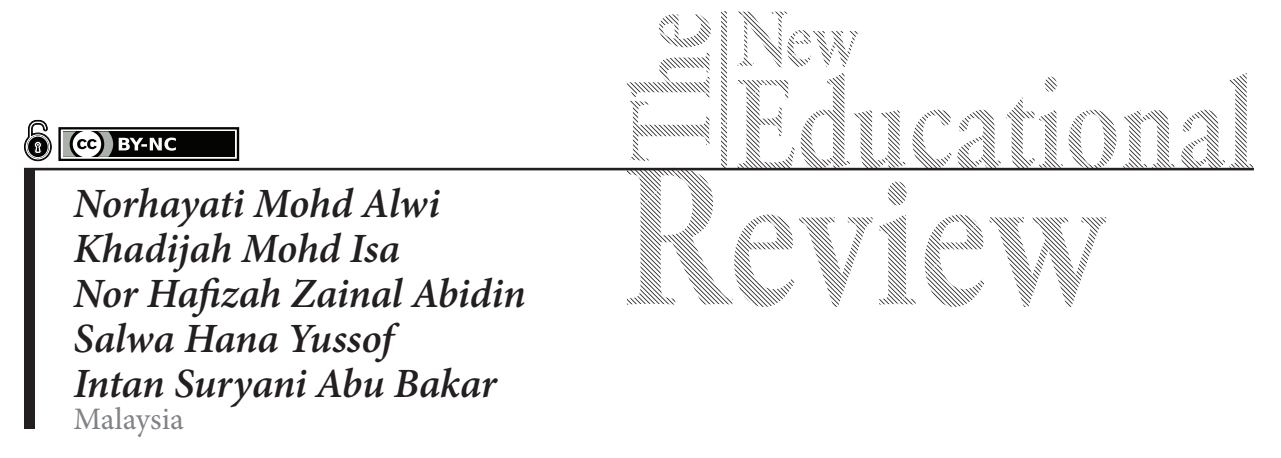

\title{
Graduate Employability Among Low Academic Achievers
}

DOI: $10.15804 /$ tner.2020.62.4.04

\begin{abstract}
This study aims to provide insights on how and why a specialised training programme could help graduates with low performance to compete fairly in the job market. This study used an action research design, where a total of 12 graduates with low academic achievement were trained under a specialised training programme consisting of two phases within the period of ten months. Despite having low academic achievements in terms of Cumulative Grade Point Average (CGPA), the employability opportunities of those graduates were high as they were equipped with the highly sought after GST knowledge and certification and various important soft skills such as time management, communication, analytical skills and leadership. This study demonstrated that engaging graduates in a specially designed program that aimed to enhance their technical knowledge and soft skills coupled with some work experience is indeed a value added strategy to enhance graduates employability. This is particularly applicable to those who are low achievers as it provides them with some kind of competitive advantages. The findings suggest that despite having low CGPA, their employability opportunities, particularly in the accounting and commercial industries, were relatively high. This study provides some guidance to policymakers and educators on how universities and industries may collaborate to mitigate unemployment issues among the accounting graduates.
\end{abstract}

Key words: Graduate, Employability, Training, Technical Knowledge, Soft Skills, $\operatorname{Tax}$ 


\section{Background of the Study}

The imbalance between the increasing number of graduates and sluggish labour market forced a lot of graduates to accept job offerings that are less commensurate with their qualifications (Yoong et al., 2016). Additionally, poor overall qualities and lack of employability skills are also notable issues of graduate unemployment (Rahmat et al., 2016). To control this situation, many governments have taken up some initiatives to revise the university curriculum and to promote additional soft skill programmes such as team building, analytical skills and English language. Despite all these efforts, the level of unemployment among graduates remained high (UNESCO, 2012). As of 2017, in Malaysia, the unemployment rate among youths aged 15 to 24 , was $10.8 \%$, three times higher compared to the country's unemployment rate of 3.4\% (The Star, 2018).

Evidently graduates are struggling to be employed due to stiff competition in the job market (Nooriah, Zakiah \& Norain, 2013). According to Tomlinson (2008), academic achievement is still seen as one of the crucial criteria for employment. This leads to an employment crisis among low achieving graduates as they have to compete with high achievers ones. Nonetheless, Ismail (2011) found that high Cumulative Grade Points Average (CGPA) did not necessarily help graduates to secure jobs. In the perspective of employers, they might not solely look at academic achievement as a significant employment factor (Aida, Norailis, \& Rozaini, 2015), thus, equipping graduates with additional skills may bring extra merit.

In terms of soft skills, graduates are well-informed of the employers' expectations on communication, analytical, professional and teamwork skills (Kavanagh \& Drennan, 2008). Previous studies indeed suggested that graduates should focus on on-going development of personal competencies, professional attitude, self-motivation and leadership, the ability to work in a team, language proficiency and employment-readiness as it would improve their employability (Atfield \& Purcell, 2010; Kavanagh \& Drennan, 2008; McMurray et al., 2011; Shafie \& Nayan, 2010).

\section{Graduate Employability}

In the labour market, supply and demand can be influenced by various economic factors and specific rules set by industries. Hence, graduates need to be flexible in meeting the demand of the industries (Wickramasinghe \& Perera, 2010). Employability refers to the party seeking a job and the other party offering the job. The literature also identified that employability comprises three main 
elements namely: a) the ability to gain initial employment; b) the ability to maintain employment and make transitions between jobs and roles within the same organisation and; c) the ability to meet new transitions between organisations (Hillage \& Pollard, 1999 in Wickramasinghe \& Perera, 2010). Certain transferable skills were seen as essential for an individual to move from one job role to another (Wickramasinghe \& Perera, 2010).

There is a significant amount of literature focusing on graduate employability and demand for the labour market (Yoong et al., 2016). The demand for labour depends to a great extent on social, economic and political changes in a society. In addition, most employers prefer graduates with soft skills rather than academic credentials alone (Aida et al., 2015; Ismail, 2011). Communication, leadership and critical thinking skills are among the soft skills that graduates should possess to competitively seek their desired careers (Atfield \& Purcell, 2010; Kavanagh \& Drennan, 2008; McMurray et al., 2011).

According to the report by UNESCO (2012), development of soft skills should not be limited within the areas of communication, analytical and leadership only. Other attributes such as integrity, adaptability, innovative, creativity, and team spirit are additional skills that are expected of the graduates.

Similar to other ASEAN countries, Malaysia also experiences high graduate unemployment rates. Che Omar and Rajoo (2016) identified several factors that contribute to the higher level of unemployment rate among the graduates, which include lack of industrial training and adverse personal attitudes. This situation raises the question as to whether or not the university's curriculum is appropriately designed in accordance with the job market demands. Indeed, the university's curriculum plays a crucial role in enhancing employability.

\section{Specialised Training, Technical and Soft Skills}

Seetha (2014) examined the ways employers selected new employees to join their workforce. The finding indicated that employers emphasised soft skills. Moreover, employers often expect the graduates to have a good command of English, be communicative, show positive attitude, and posesss leadership skills. Graduates with outstanding academic credentials and relevant competencies would have a greater opportunity to be employed (Jayasingam, Fujiwara \& Thurasamy, 2016).

On-the-job training and specialised training are among the programmes that add value to the graduates in preparing them for the job market. According to 
Abdul Hamid et al. (2013), on-the-job training equips graduates with the latest skills demanded by the industries. During the on-the-job training, graduates could learn how to apply all the theories that they have learnt at the university to the actual tasks in the real world. This will therefore further enhance students' understanding of what was learned before, and hence increase their competency and confidence level to enter the actual work environment.

The stiff competition in the job market, high expectations from industries on graduates' academic performance, technical and soft skills, lead to an employment crisis among low-achiever graduates. Therefore, this study is conducted to provide some insights into the outcome and impact of offering a specialised programme to low-achiever graduates.

\section{Research Objectives}

This study aims to explain how and why a specialised programme will benefit graduates with low academic achievement in enhancing their technical knowledge, soft-skills and self-esteem. Further, this study also intends to examine how and why a specialised programme provides some directions of the graduates' career paths.

\section{$\underline{\text { Research Methodology }}$}

This research employed an interview technique to collect narrative data from graduates who had participated in a specialised training programme. The interview was conducted almost two years after the end of the programme to observe the outcome and impact of the programme towards the employability of the graduates. Twelve graduates with 'low' CGPA, specifically below 3.0, were selected. The main reason for the selection of this group of graduates was to assess whether providing a specialised training programme could enhance their employability or not, despite having low CGPAs.

The specialised training programme was conducted in two phases. Phase 1 was a two-week workshop on Goods and Services Tax (GST) (which was newly implemented in Malaysia at that time) and employability skills. The workshop on employability skills covered topics that could improve self-management and enhance personal soft skills of the graduates, which include self-attitude, motivation, adaptability, time management, teamwork, leadership, stress management, 
problem solving, report writing and communication. Phase 2 was a six-month work attachment at several participating accounting firms. In addition, during the Phase 2 of the programme, the graduates had also attended a six-day GST training course and examination organised by the Royal Malaysian Customs. Upon passing the examination, they can apply to be a licensed tax agent.

\section{Findings and Discussion}

All participants in the GST specialised training programme were employed at the time of the interview. Findings from the interviews with the participants are discussed below.

\section{Low Academic (CGPA) Achievements}

Results showed that the three main reasons for low achievements resulted from personal attributes, failure in non-accounting courses and environment. One participant referred to 'personal reason' as his aversion towards an accounting programme. Despite the participant's interest in law, his parents wanted him to pursue accountancy. He then ended up enrolling in the accounting programme half-heartedly and consequently failed to perform. He emphasised that his low achievement was not because of the education system, but mainly due to his lack of passion in accounting.

It was also acknowledged that low CGPA results could also be attributable to students' poor performance in other non-accounting (general) subjects, namely economics, languages, and Islamic studies. Additionally, students' attitude, studies and performance might also be influenced by other factors including selection of friends, lifestyles and the university's environment overall. It is deemed vital for students to choose friends appropriately that could bring about some positive vibes as well as inspirations to succeed. Perhaps, having friends from a similar course and background helps students to perform better.

\section{Low Academic Achievement (CGPA) and Employability}

Overall, the participants believed that examination results (CGPA) had a low or no relationship with employment opportunities. The findings suggested that high 
CGPA did not guarantee job performance. One participant shared his experience as follows:

“...Even though the job advertisement stated that a minimum CGPA 3.0 was required, I still applied for the post. I got through the interview because the potential employer was comfortable with (my) one-year (working) experience...he [the employer] said that you were better than the fresh grad who had 4.0 flat..."

An opportunity to attend an employment interview often allows graduates to demonstrate and sell the talents and skills they possess. Personal appearance, communication skill (e.g. English language), IT skills and self-esteem are often deemed to be critical factors considered by potential employers besides the CGPA.

According to the participants, low achieving graduates could indeed further improve themselves in the workforce. Nonetheless, CGPA was still relevant, especially if they wanted to work in government agencies, big accounting firms or government-linked companies (GLC) that required a minimum CGPA of 3.0.

Having professional accounting certificate or any other certificates may also provide additional value to graduates in securing better career opportunities. During the specialised training programme, all students were required to sit for a GST examination conducted by the Royal Malaysian Customs. In spite of having a low CGPA (i.e. below 3.0), ten participants (83\%) passed the GST examination. Passing the examination enabled the graduates to obtain a GST certificate, coupled with the degree qualifications, would further add value to the graduates' credentials and hence, enhance employability.

One participant expressed his gratitude that he had gained much knowledge from the GST course despite failing his examination. Another participant mentioned that her failure in the GST examination was mainly due to the timing of the examination coinciding with the peak period for GST filing. This left her with a rather little time to prepare for the examination. She recalled:

“...I remembered it was October when I was busy with my first GST (filing) submission. I needed time to adapt to the compliance requirements. There were only 2-3 staff assigned to the GST. The GST training was for two weekends, and the examination was at the end of the month. To balance between the job and exam (at that time) was difficult. That was why I failed (the GST exam)..."

Furthermore, the working experience gained through the arrangement embedded in the specialised programme would also add value and help those low 
achievers to climb up the ladder to achieve better career opportunities. As stated by one participant, "that programme is useful for working".

\section{University Education and Employability}

Participants shared their opinions on the relevance of university education in their daily job scope. Generally, participants agreed that university education was essential in providing a strong foundation and theoretical grounds. For example, the knowledge was useful for some of the workplace tasks, particularly relating to basic accounting entries and syllabus in accounting courses in third and fourth year. Nonetheless, they only realised the link between the university education and accounting practices when they had to perform their workplace duties. As mentioned by one participant:

“...with the knowledge that I brought from university, when I started working at Firm Y, I felt like an idiot. I did not know anything. But throughout the practice, I slowly realised that what I was doing was taught by various lecturers during my study, and it appeared that the theory and the practice were connected. Only then I realised how the university's education became relevant and getting into the picture. You needed working experience to see all these. Without it, you could not see..."

Another participant also agreed that some courses, such as audit and taxation, are very practical; hence knowledge gained during university education could be directly applied in the workplace. The university education received is important as it provides the fundamental background to understand and apply the knowledge further at the workplace. The ability to speak and write in English provides an additional advantage to the participants especially if English is used as a medium of instruction at the university.

\section{GST Specialised Training and Employability}

Findings from the interviews suggested that the specialised training conducted had improved self-esteem and confidence level of the participants. As supported by one participant, "I have improved not just about GST. I have learnt other skills too, including communication skills. So, the programme was okay". 
One of the participants commented, "...Maybe one of the reasons they put me in that department, the Middle East, actually was due to the GST knowledge. During the interview, they asked me about the GST, what I know about the GST..."

Another participant had also positively commented on the offering of the specialist programme. The participant claimed that “...This GST specialist training was very good ...It was good because when I started to work, I was ready, I didn't blur anymore..."

Despite their low academic achievement (CGPA), their employability opportunities were high mainly due to having a competitive advantage (GST technical knowledge and soft skills) in the job market, especially in accounting firms and commercial industry. In short, the specialised programme did benefit the participants by providing them with a higher chance to secure an employment in various companies.

\section{GST Specialised Programme and Soft Skills}

The specialised training programme enhanced participants' technical knowledge and soft skills. In terms of technical expertise, the participants were given the opportunity to acquire knowledge and skills of GST, which were highly demanded by accounting and commercial firms. Moreover, the training improved their verbal and written communication skills. In short, the training prepared them with some career guides and served as a platform for future job opportunities.

The training also increased the participants' level of self-esteem despite their low academic achievements. With a competitive advantage of having GST knowledge, the participants were more confident in delivering their job routines and dealing with supervisors and colleagues during their industrial attachment. They also earned higher income as they had additional GST knowledge.

The technical skills of GST were seen as an added value to the low achievers. One participant revealed the following:

“...Yes, when I was called up by my manager at $\mathrm{ABC}$, he was expecting something from the knowledge that I have (GST knowledge). Because right now, once I am familiar with the system, then it's time for me to improve the system. So, the way I see it, they expected more from me compared to their other employees that they hired at the same time. Because during my enrollment, there were other three new employees, 
together we came and we started in $\mathrm{ABC}$, so they were all fresh graduates, I was the only one with experience, so that's why..."

On the communication skills, one participant also commented,

"...yes, it helped in terms of communication with the clients. The training did improve communication skills, such as sending emails to clients. I had the confidence to speak to the clients. Furthermore, the training also improved (my) self-esteem..."

\section{GST Specialised Training and Career Path}

Being low achievers, many participants confessed that they did not seem to be particularly aware of the career path that they should pursue after they completed their studies. The study suggested that the specialised programme had given them some guidelines on their career direction. As mentioned by one participant:

"...The knowledge on audit experience (that I gained in Firm Y engagement) was helpful when I was completing my work at BCD. Basically I had constructed BCD's account by applying the audit and accounting knowledge which I had gained from firm Y, so it was connected in a way..."

He stressed further by saying, "Putting it differently, if I didn't join this programme, I would not know where to work, where to apply, and which industry is suitable for me. I would be lost."

Another participant commented on the relevance of GST to his career path:

“...The programme like GST was really good since after graduation, we could be employed immediately. If I did not enrol in the programme, I was not sure whether I would be employed by the firm. By getting employed upon graduation, it opened up many career paths to me. The programme was really helpful (especially to me)..."

Another participant added, “...In terms of getting a job, I did not have to worry. It was hassle-free because the programme was bundled with a job engagement. Furthermore, we have had six months practical training experience..." 


\section{Conclusion and Recommendations}

This research demonstrates the impact of a specialised training programme on the employment opportunities of low achieving graduates. It provides some empirical evidence on the benefits that could be derived from engaging low achievers of accounting graduates into a specialised training programme, designed to enhance their specific technical knowledge as well as soft skills in order to improve their employability. The findings of the research also suggest that such training programmes must be relevant and timely to the current needs of the industry. An appropriately designed programme shall prepare the graduates to face the real working environment with confidence and high self-esteem.

\section{Acknowledgement}

Appreciation to the Ministry of Higher Education, Malaysia for Graduate Employability Fund and the Faculty of Economics and Management Sciences, International Islamic University Malaysia for financial support under IAREF fund: IAREF16-003-0009.

\section{References}

Abd. Hamid, M.S., Islam, R., \& Abd Manaf, N.H. (2013). Enhancing Malaysian graduates employability skills: quality function deployment approach. Proceedings of the International Symposium on the Analytic Hierarchy Process 2013.

Aida, B., Norailis, A.W., \& Rozaini, R. (2015). Critical success factor of graduate employability programs. Journal of Economics, Business and Management, 3(8).

Atfield, G. and K. Purcell (2010) 'Job search strategies and employment preferences of final year undergraduate students', Futuretrack Working Paper 2, Institute for Employment Research

Che Omar, C.M., \& Rajoo, S. (2016). Unemployment among graduates in Malaysia. International Journal of Economics, Commerce and Management, 4(8).

Ismail, N.A. (2011). Graduates' characteristics and unemployment: A study among Malaysian graduates, International Journal of Business and Social Science, 2(16).

Jayasingam, S., Fujiwara, Y., \& Thurasamy, R. (2016). 'I am competent so I can be choosy': Choosiness and its implication on graduate employability. Studies in Higher Education, 43(7), 1119-1134.

Kavanagh, M.H., \& Drennan, L. (2008). What Skills and attributes does the accountant graduates need? Evidence from student perceptions and employer expectations. Journal of Accounting and Finance, 48.

McMurray, I., Roberts, P., Robertson, I., \& Teoh K. (2011). An action research project 
exploring the psychology curriculum and transitions to employment. Psychology Teaching Review, 1(1).

Nooriah Yusof, Zakiah Jamaluddin \& Norain Mat Lazim, (2013) Persepsi pelajar prasiswazah terhadap kebolehpasaran graduan dan persaingan dalam pasaran pekerjaan (Perception of undergraduates on graduate employability and labour market competitivess). Jurnal Personalia Pelajar (16). 77-92.

Rahmat N., Ayub A.R., \& Buntat Y. (2016). Employability construct as job performance predictors for Malaysian Polytechnic graduates: A qualitative study. Malaysian Journal of Society and Space, 12(3).

Seetha, N. (2014). Are Soft skills Important in the Workplace? - A Preliminary Investigation in Malaysia. International Journal of Academic Research in Business and Social Sciences. April, 4 (4)

Shafie, L.A., \& Nayan, S. (2010). Employability awareness among Malaysian undergraduates. International Journal of Business and Management, 5(8).

The Star. (2018, Aug 6) Young and Jobless in Malaysia. The Star. Retrieved from https:// www.thestar.com.my/business/business-news/2018/08/06/young-and-jobless-in-malaysia/

Tomlinson, M. (2008). The degree is not enough: Student's perception of the role of higher education credential for graduates' work and employability. British Journal of Sociology Education, 29(1).

UNESCO (2012). Graduate Employability in Asia. ISBN: 978-92-9223-395-2 (Electronic version), pp. 59-85.Publisher: UNESCO Bangkok

Wickramasinghe, V. \& Perera, L. (2010), Graduates', university lecturers' and employers' perceptions towards employability skills, Education + Training, Vol. 52 No. 3, pp. 226-244. https://doi.org/10.1108/00400911011037355

Yoong, D., Mohd Don, Z., \& Foroutan, M. (2016). Prescribing roles in the employability of Malaysian graduates. Journal of Education and Work. 